Original Research Paper

\title{
Contrastive Analysis of Stretched Collocations with Get and Take: Their use and Pedagogical Implications
}

\author{
Silvia Molina Plaza \\ Department of Applied Linguistics, Technical University of Madrid, Spain
}

Article history

Received: 26-12-2014

Revised: 13-01-2015

Accepted: 30-05-2015

\begin{abstract}
This paper explores the pedagogical implications of contrastive analyses of light verb constructions containing get and take in English and Spanish based on electronic corpora, the British National Corpus (BNC) and the Corpus de Referencia del Español Actual (CREA). The main tenets of collocations from a contrastive perspective-and the points of contact and departure between both languages-are discussed prior to examining the commonest types of verb+ noun combinations (i.e., take a bath, take advantage of), verb+ adjective (i.e. get ready, get worse, get angry), verb+ participle (i.e., get married, get dressed) as significant cases of so-called "light", "empty", "thin", "stretched" or "support" verbs. A quantitative and qualitative-oriented case study is accordingly conducted, determining the weight of get and take in stretched collocations in the BNC and of the Spanish equivalent verbs constructions within the CREA. Based on empirical data obtained this way, this paper provides relevant insights for more accurate translations, helping to enhance the collocational competence of L2 students, who tend to avoid constructions including empty verbs in favour of full verb forms. The findings in this study shed light on the potential of corpora resources for improving the collocational usage of foreign-language learners, as quantitative and qualitative comparisons of collocations serve to highlight the similarities and, more importantly, the lexical, cognitive and typological differences between these phraseological constructions in the two languages, thereby substantiating the very useful role that corpus analysis may play for language teaching in general and for collocational knowledge and proficiency in particular.
\end{abstract}

Keywords: Collocations, Light Verb Constructions, Translation, Teaching Phraseology

\section{Introduction}

\section{Stretched Collocations at the Crossroads in English and Spanish Phraseology}

Phraseology is definitely concerned with the study of those chunks which, be they collocations or idioms, constitute some crucial cognitive, textual and pragmatic tools to be mastered by the language learner. As Sokolik (2001: 487) underlines in her overview of ComputerAssisted Language Learning (CALL), "corpus linguistics and concordancing can help provide the data and tools that students and instructors need to make sense out of usage". CALL applications and phraseology may thus provide invaluable resources for the student's knowledge of multiword units such as delexicalized verb constructions. These semi-compositional verb-noun constructions have been investigated under various labels in the different linguistic traditions. Other terms that are in use to denominate such constructions, parts of them, or a superset of semi-compositional expressions which will be used in this study are light verbs, operator verbs, complex predicates, support verb constructions and others. There is no consensus among the authors about what structures are admissible and different studies investigate non-identical structures. Despite this proviso, in English linguistics, the common ground is that the structures should be non-compositional and consist of a semantically low-content, inflected verb and a predicate noun (Nickel, 1968; Wierzbicka, 1982).

Prior to undertaking a detailed case study exploring this phenomenon and its implications for language 
learning, some remarks will be made on CALL, phraseology and their interface.

\section{CALL and its Role in Improving L2 Learning}

CALL has become a new, but well-established, scholarly domain researching the pedagogical possibilities provided by computers and the Internet for increasing language learners' communicative skills (Warschauer and Kern, 2000; Warschauer, 2001; Blake, 2001; Davies, 2002; Godwin-Jones, 2005; Oster et al., 2006). CALL may be broadly defined as "any process in which a learner uses a computer and, as a result, improves his or her language" (Beatty, 2003: 248). Evolving from more technical approaches to and definitions of the term CALL, such as Levy's (1997), to the emphasis on its pedagogical implications (Egbert, 2005), the notion of CALL has come to be "used to describe the introduction of computers into the field of L2 learning and teaching” (Ruiz-Madrid, 2007: 64).

Bearing this context in mind, this paper is focused on project-based learning (Beckett and Miller, 2006) exploring how collocational competence in general and support verb constructions in particular may be integrated into English language programs in the Technical University of Madrid from B2 level onwards. I also concentrate on some specific types of collocation, get + collocate and take + collocate, in the two languages, in order to ascertain the points of contact and departure.

\section{Phraseology: Definitions, Contrastive Analysis and Use}

Phraseology has now come of age. For a long time, both linguists and psychologists have paid attention to multi-word units as syntagmatic patterns (Firth, 1951: 190-215; Cowie, 2004: 37-52) and tried to analyze how they are represented in the lexicon. They have noticed that language is acquired in cohesive lexico-grammatical clusters or 'chunks' which capture everyday experiences and constitute crucial cognitive, textual and pragmatic tools to be mastered. Many authors have highlighted the enormous difficulty in clearly defining and delimiting this complex of features that interact in various, often untidy, ways and represent a broad continuum between non-compositional-or idiomatic-and compositional groups of words (Moon, 1998:6). This author calls them Fixed Expressions and Idioms (FEIs).

These FEIs or chunks are usually examples of formulaic language (Nattinger and de Carrico, 1992; Wray, 2005), in which word strings occurring together tend to convey holistic meanings that are either more than the sum of the individual parts or else diverge significantly from a literal, or word-for-word meaning and operate as a single semantic unit. Gries (2008: 4 and ff.) identifies a set of parameters worthy of attention that are typically implicated in phraseological studies:

- The nature of the elements involved in the phraseologism

- the number of elements involved in a phraseologism

- The number of times which an expression must be observed before it counts as a phraseologism

- The permissible distance between the elements involved in a phraseologism

- The degree of lexical and syntactic flexibility of the elements involved

- The role that semantic unity and semantic noncompositionality/non-predictability play in the definition

He then defines what a phraseologism is (op. cit., 2008: 6), a definition accepted in this study: "the cooccurrence of a form or lemma of a lexical item and one or more additional linguistic elements of various kinds which functions as one semantic unit in a clause or sentence and whose frequency of co-occurrence is larger than expected on the basis of chance".

\section{Bridging the Gap between CALL and Phraseology}

An exploration of the literature on the subject reveals that work in CALL has focused on various topics related to lexicography such as on-line dictionaries and the introduction of their use as part of CALL (Campoy, 2004: 47-72); use of audio files in computer mediated dictionaries (Sobkowiak, 1999: 246 ff.); dictionary usage guidance in paper dictionaries versus online dictionaries (López and Campoy, 2003); user typology (de Schryver, 2003: 151); or simultaneous look-up in dictionaries with the same information (Luzón, 1999), to quote a few relevant examples. The use of concordance programs has also been discussed as another means for vocabulary and grammar practice where "the students can view many examples of usage and compare them to their own writing without having to search manually through many pages of text" (Hanson-Smith, 2004: 111) as well as online concordancers which help students use search engines to find typical collocations and grammatical or rhetorical items on the internet (Mills, 2000). However, little work has been done so far on specific types of collocation that support verb constructions, which are frequent in oral and written genres. Our examples in English and Spanish reveal that these flexible collocations are widely used in discourse simply because they are adaptable to a wide range of situations. However, we have noticed that non-native speakers tend to underuse these de-lexicalized collocations. Therefore, CALL is a useful means of paying attention to them, enhancing the students' production and understanding of these phrasemes as well as improving their communicative competence in general. 


\section{Scope, Purposes and Methodology}

The studies in $\mathrm{L} 2$ raise an awareness that a significant proportion of the language that we produce is made up of collocations and idioms, labelled as formulaic sequences or phrasal units by other authors (Sinclair, 1997: 82). If this is the case for native speakers, a logical consequence is that learners of English will also find these formulaic sequences very important and useful as stated in different studies (Lewis, 2000; Nattinger and DeCarrico, 1992; Richards and Rodgers, 2001).

Keeping this context in mind, it is fairly obvious that teachers should try to increase the acquisition of these sequences by learners and design teaching materials highlighting the similarities and differences between English and Spanish. Several studies have already highlighted that collocational patterns are difficult for non-native speakers (Wray, 1999: 468 among others). Students tend to use less these collocations than native speakers, as pointed out by Howarth (1996) and sometimes "blend" two collocations with a similar meaning. For instance, "have/get" combinations. In general, the verb "have" is used with things we possess and the verb "get" meaning "to receive something". Students blend the adequate LVC, get stars with a wrong alternative, have stars, as in the following example: That restaurant got three stars in the 2010 Michelin guide.

In section 2 of this article I pay attention to a subgroup of these collocations known as de-lexicalized, light, empty, thin, stretched or support verbs (Jespersen, 1942, Mel'čuk, 1993; Allerton, 2003). The analysis in the case study may also serve as an example of the implications of collocational usage in light verb constructions by foreign language learners.

More specifically, the focus of this study is to determine the weight of get and take LVCs in the British National Corpus (BNC) and how comparable LVCs are translated into Spanish in section three. I also use comparable corpus in Spanish, CREA, to study the most common expressions corresponding to the BNC. Both corpora have over a 100 million words, are linguistically representative and easy to access. All the uses of these verbs are extracted automatically. All usages of Light Verb Constructions (LVCs) are selected manually. The examples were then analyzed in terms of translation. The final aim of this study based on empirical data is to provide relevant insights for more accurate translations and to enhance the collocational competence of L2 students (Bahns, 1993), who tend to avoid these constructions in favour of full verb forms (i.e., to access, bathe, etc). Examples from teaching experience show that the translation of collocations is difficult for nonnative speakers. They also prove that many collocation translations are idiosyncratic in the sense that they are unpredictable by syntactic or semantic features. Taking a broader pedagogical perspective drawing upon the implications of corpora for language learning and teaching, the aim here is to demonstrate that combined and integrative use of phraseology and CALL may thus provide most helpful insights not only for contrastive collocational analyses across languages but, more importantly, for foreign language learners and teachers who need to acquire collocational knowledge and competence. A former study of give collocates in English and Spanish proved the suitability of this contrastive teaching approach (Molina-Plaza and Gregorio-Godeo, 2010). Arguably, quantitative and qualitative comparisons of collocations based on electronic corpora are greatly needed to highlight the similarities and, more importantly, the lexical and typological differences between both languages for the English as a Second Language (ESL) learner.

\section{Light Verb Constructions in English and Spanish}

This study focuses on the identification of relevant Light Verb Constructions (LVCs) with get and take from a quantitative point of view in English, as such constructions play a prominent and productive role in many other languages (Butt and Geuder, 2001; Miyamoto, 2000). Although the exact definition of a LVC varies in the literature, I use the following definition:
A light verb/support verb construction is a verb-complement pair in which the verb has little lexical meaning (is "light") and much of the semantic content of the construction is obtained from the complement.

Examples of LVCs in English include "give a speech", "make good (on)" and "take (NP) into account". In the case in which the complement is a noun, it is often a deverbal noun and, as such, can usually be paraphrased using the object's root verb form without (much) loss in its meaning (e.g. take a walk $\rightarrow$ walk, make a decision $\rightarrow$ decide).

The basic properties of these constructions are the following, according to several studies (Mel'cuk, 1996; Traugott, 1999; Wierzbicka, 1982):

- On average, the nominal element is preceded by an indefinite article, which has a delimiting effect on the noun (Wierzbicka, 1982: 758)

- A Support Verb Construction (SVC) consists of a predicative noun and a support verb

- The basis for the description of a SVC is the formal specification of the argument structure of the predicative noun. The noun is not semantically reduced or shifted with respect to a usage in compositional constructions 
- The essential idea of a SVC is the realization of the arguments (i.e., the semantic actants) of the predicative noun as syntactic actants of the support verb. In prototypical LVCs, the verb does not semantically subcategorize any of its syntactic complements. This means that the noun is the predicate of the construction, the verb has mainly syntactic relevance

- The predicative noun is realised as head of a noun phrase in a syntactic slot provided by the light verb; in many cases but not always this is the direct object position

- The semantics of the light verb is either void or reduced to a small set of semantic features that are relevant for very large subclasses of verbs (basically lexicalized aspect, which is applicable to event/action verbs or amplification/attenuation)

- This means that prototypical LVCs are semicompositional structures consisting of a semantically transparently used noun

- Not any light verb can combine with any event nominal (e.g. *make a bath, *give a jog). Furthermore, some limitations are idiosyncratic (American/British make a decision versus Britishonly take a decision). This poses problems for learners and at least some constructions must be learned and stored in memory as quasy-idioms

- From a diachronic perspective, LVCs do not lessen in form (e.g., become auxiliaries or affixes) and they do not lead to the development of functional categories (Traugott, 1999: 257)

Although the corresponding full verb constructions are more frequent than the LVCs, it is essential for advanced learners (from B2 level onwards) to learn them because there can be nuanced differences in meaning across these alternative formulations. The LVCs produce possibilities for modification that are less available with the corresponding full verb alternatives.

\section{Case Study: Contrastive Analysis of LVCs with Get and Take in two Comparable Corpora}

LVCs form a cline of idiomaticity from 'clearly idiomatic expressions' (e.g., get good/bad press) to 'relatively idiomatic expressions' such as take a walk, make a statement, where the meaning of individual words is retained up to a certain extent and there are expressions that retain the core meaning of these verbs at the other extreme (Biber et al., 1999: 1027): e.g., you can take a snack in your pocket, he made a sandwich. These support verbs (e.g., do, make, get, give, do, take and have) are, according to corpus research, some of the most frequently used words in the English language. They are also particularly important for speakers of Latin languages because students avoid or do not even feel the need to use them as there is normally a one word translation between their L1 and English. However, when speaking, learners can sound odd or strange to the native speaker as their choice of language is different.

I decided to analyze LVCs with get and take, which are halfway between full lexical verbs and auxiliary verbs, in the BNC and wanted to compare them with their Spanish homologues in the CREA, as the literature on this topic points out that in languages such as French, Italian, Spanish and English, support verb constructions are semi-productive (Wierzbicka, 1982; Alba-Salas, 2002; Kearns, 2002). Both corpora are considered comparable in corpora studies (Hornero et al., 2006) as they are both over 100 million words, despite the fact that there are differences in the way they have been compiled.

Hence, the data in this study consist of 10,643 support verb collocations in English with get and take and their Spanish translations, in most cases attested in bilingual dictionaries and bilingual translated texts from the EU website and other well-known websites (i.e., UN, big companies such as Coca-Cola) using the web as corpus. I have tried to choose noun and adjective/participle collocates with a high frequency in both languages. My references in Spanish are Ueda (1989), who selected the most common nominal collocates $(2,727)$ and the dictionary Diccionario de Uso del Español (Dictionary of Spanish Usage) by Moliner (2000), as it indicates the verb collocates that usually go with the de-lexicalized base. In English the raw frequencies of the infinitives comprise occurrences in all the BNC subcorpora (including past tenses) and in Spanish I have followed the same criterion with the CREA. I have excluded number variation. A simplified version of the following data was used in the English for Professional and Academic Communication class at the Technical University of Madrid for third year students of Naval Engineering with a B2 level (course 2012-2013). Therefore, it is also a pedagogical proposal for teaching the LVCs in the 2 classroom.

\section{English LVCs with Get}

\section{Methodology and Quantitative Analysis}

Twenty-six phrases combining with get in the infinitive form were selected using concordances. Three types of sources were used to determine the degree of acceptability of the LVCs that have been extracted from the corpus: Dictionaries, corpora and native speakers. LVCs were judged acceptable if they appeared in identical forms and with the same intended meaning in well-known dictionaries (OED, LDOCE, the BBI Dictionary of English Word Combinations, etc.).

Most nouns combining with get are abstract (e.g. attention) in comparison with other common collocations in the oral register with other support verb 
constructions such as have a baby, etc. The raw number of tokens for LVC verb + noun constructions is 913 . It is also relevant to note that verb + adjective and verb + participial adjective (Often the difference between the adjective and the participle is not clear-cut. For the-ed form the participle interpretation focuses on the process, while the adjective interpretation focuses on the state resulting from the process (Quirk et al., 1990: 135) constructions outnumber by far verb + noun constructions as there is a total of 2,810 raw tokens. The overall number of these constructions in the BNC is 3,723 . The infinitive and the past tense are included in the counting. See Table 1 and Fig. 1 for an overview of the commonest use of verb+ noun constructions. Some of these expressions take no article: get access, get advice. Besides, there are combinations in which the noun is a prepositional object (e.g. take into consideration) and combinations in which the noun is phonetically and derivationally related to a verb (e.g. take a look-look, take a breathbreathe). Verb and adjective combinations have also been included, following Allerton (2003) and combinations which have an equivalent verb in the passive (e.g. take offence- be offended).
Adjectival LVCs with get occur abundantly in written and oral texts in the BNC. The most common ones are shown in Table 2 and Fig. 2.

\section{Discussion of LVCs with Get and Their Translation into Spanish}

These LVCS provide a useful difference in tone or emphasis, as between the sentences The 15-M demonstrators were arrested and The 15-M demonstrators got arrested. The first example implies that the responsibility for the arrests rests primarily with Madrid's police, while the example using get implies that the demonstrators deliberately provoked the arrests. It is also interesting to note that in colloquial use and in several nonstandard varieties of American English, the past tense form got has the meaning of the present as in I got a lot of problems. When translated incorrectly, LVCs have a negative impact in the understandability and quality of translations (Barreiro et al., 2013). The contrastive analysis of these constructions in the ESL class helps to avoid this common trap.

Table 1. Get LVCs with noun collocates in the BNC

\begin{tabular}{lcl}
\hline $\begin{array}{l}\text { LVCs with } \\
\text { get }+ \text { noun }\end{array}$ & $\begin{array}{l}\text { Number of } \\
\text { tokens in the BNC }\end{array}$ & Example \\
\hline get an abortion & 8 & CH5 992 The girl had asked me how to get an abortion. \\
get access & 75 & CCX 1743 It isn't easy to get access to the outside walls of my house. \\
get advice & 49 & AKL 624 You can hire an architect or get advice on digging drains. \\
get an answer & 51 & AA9 558 It shouldn't be too long before we get an answer. \\
get approval & 17 & HHV 5716 Unfortunately, it did not get approval from the Civil Aviation Authority. \\
get attention & 26 & BNA 1168 So do not feel you have to make a fuss to get attention. \\
get an award & 7 & J1J 1180 I've never been so pleased to see Will Carling and the boys get an award. \\
get a divorce & 21 & C9U 1628' He now finds he cannot get a divorce. \\
get hold of & 664 & All they were interested in was striking deals to get hold of petrol, which was \\
& 62 & in very short supply (ADP 831) \\
get permission & A70 389 And there is the likelihood that they won't get permission to take their child home. \\
get the sack & 65 & CH3 4460 My bet is that Liverpool won't win anything this year and Souness will get the sack. \\
get a/the shock & 27 & B2E 1212 I did get a shock. \\
get into an argument & 6 & CEN 5055 The two men had got into an argument after Brazil said he was \\
& & going to start dealing in drugs (...)
\end{tabular}

Table 2. Get LVCs with adjective/ participial adjective in the BNC

\begin{tabular}{|c|c|c|}
\hline $\begin{array}{l}\text { LVCs with } \\
\text { get }+ \text { adjective }\end{array}$ & $\begin{array}{l}\text { Number of } \\
\text { tokens in the BNC }\end{array}$ & Example \\
\hline get angry & 99 & ADA 107 I have no wish to get angry with my own invention, the so-named Miller. \\
\hline get arrested & 25 & BP9 2292 'Val would presumably prefer you didn't get arrested. \\
\hline get dressed & 198 & AC2 849 She kissed him lightly on the lips and rose from the bed to get dressed. \\
\hline get drunk & 187 & $\begin{array}{l}\text { A7C } 702 \text { The idea of the evening was primarily to get drunk and this was a matter. } \\
\text { about which Lewis was exuberantly insistent. }\end{array}$ \\
\hline get lost & 364 & $\begin{array}{l}\text { B2T } 1534 \text { Rational planning models have several shortcomings-there is the } \\
\text { danger that the plan becomes all important, the wider goals get lost. }\end{array}$ \\
\hline get married & 893 & HHA 3929 That sounded as if he was planning to get married soon. \\
\hline get ready & 281 & CFJ 917 It's time to get ready for school.' \\
\hline get smt. straight & 22 & H85 1520 If she let the subject go cold on her, then she never got it straight in her mind. \\
\hline get stuck in & 93 & BMS 1659 What if I get stuck in this place? \\
\hline get stuffed & 40 & AC2 159 Under his breath, the Vice President was telling him to get stuffed. \\
\hline get washed & 27 & K4V 1168 The following day he records: 'Rose at $6 a m$, got washed ready for going shore. \\
\hline get wet & 84 & A6T 1690 Then everything must go in plastic bags so the car doesn't get wet. \\
\hline get worse & 325 & A8K 623 Mrs Thatcher's style almost obliges this division to get worse. \\
\hline
\end{tabular}



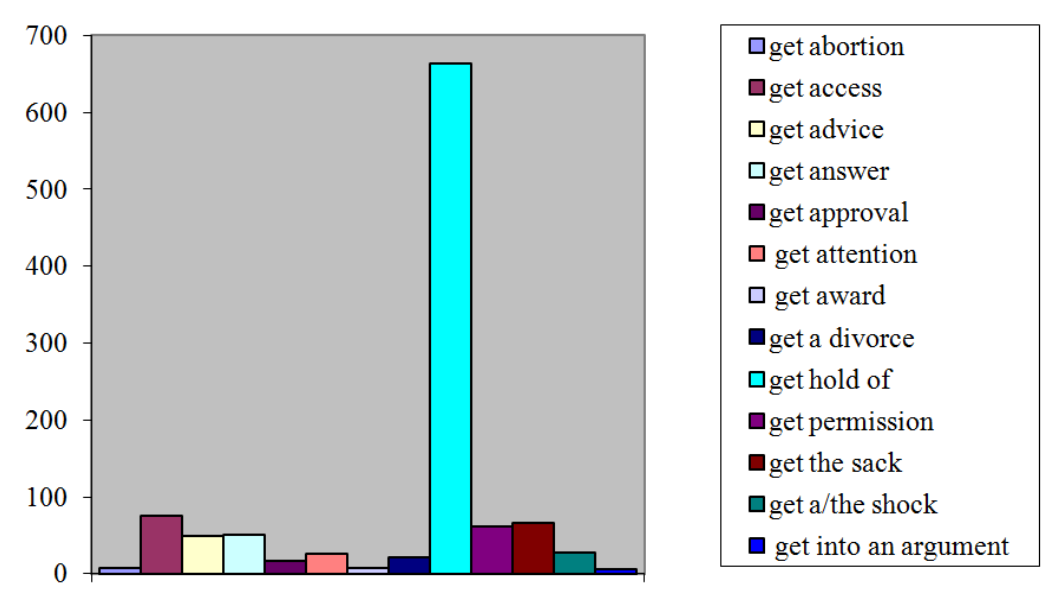

Fig. 1. Get LVCs with noun collocates in the BNC

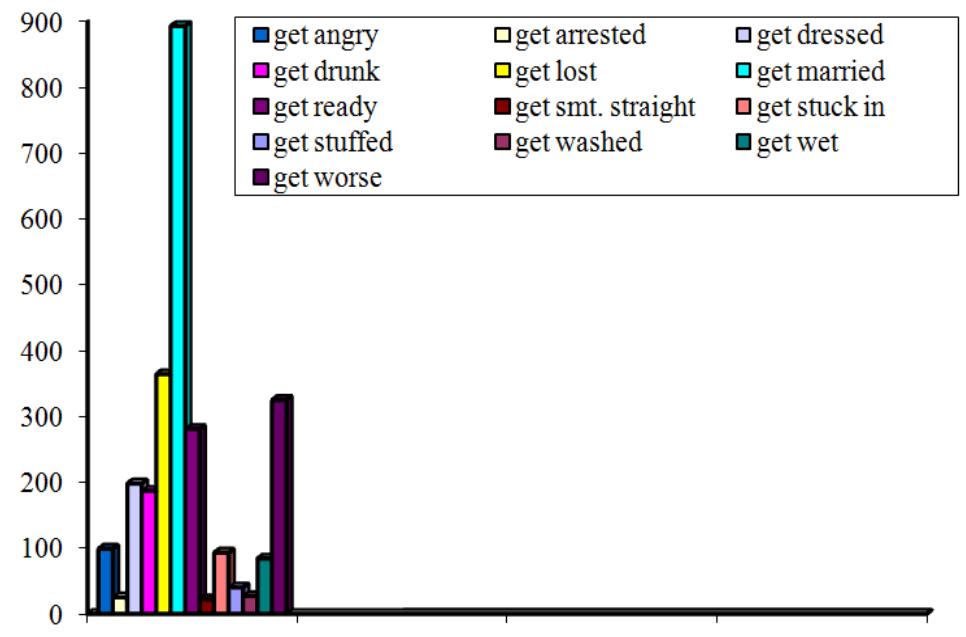

Fig. 2. Get LVCs with adjectives and participles in the BNC

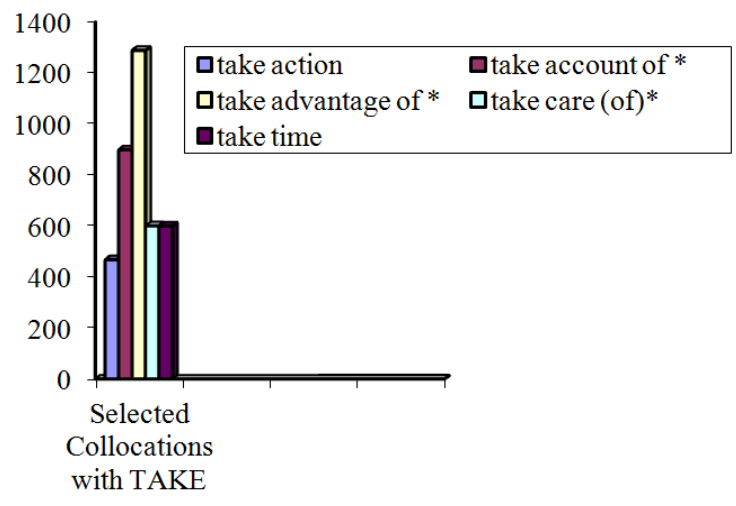

Fig. 3. Selected Take LVCs in the BNC

\section{Get LVCs with nouns}

These LVCs are less frequent quantitatively compared with full lexical verbs but students are advised to use them at a B2 level, according to the recommendations stated by the Common European
Framework of Reference for languages (Table 3 and Fig. 3). From a quantitative point of view, the highest number of occurrences is get hold of, get access, get permission and get the sack.

\section{Get Hold of}

This is the most frequent LVC. Three types of translation were identified in real usage examples:

- English construction $\rightarrow$ Different Spanish full lexical verb

(1) El Rocallís' is made from the Incroccio Manzini grape variety, "I came across this variety in the $[\ldots] 80 \mathrm{~s}$ in Verona and, despite its scarcity, I managed to get hold of some plant plugs which [...]" $>$ El Rocallís' se hace con uvas de la variedad Incroccio Manzoni, “conocí está [...] variedad en los años 80 en Verona $y$, a 
pesar de su escasez, conseguí unos plantones que [...]." (winesfromspain.com)

(2) But how can one comment on a text if there is neither the time nor the opportunity to get hold of it?>Pero ¿qué efecto podría surtir el texto si no se previera tiempo y oportunidad para examinarlo,...? (unesco.org.)

- $\quad$ English construction $\rightarrow$ Spanish noun

(3) A clear majority of those interviewed think that it is easy to get hold of drugs > Una clara mayoría de las personas interrogadas considera que el acceso a la droga es fácil (europa.eu)

- $\quad$ English construction $\rightarrow$ Spanish LVC construction

(4) Actually the challenge was to kind of try and get a hold of what was expected of me, (...)> El desafío consistía verdaderamente en intentarlo y mantenerme a la altura de lo que se esperaba de mí (...), (europeancareers.coca-cola.com

As shown in examples 2 to 4 , the translation of get hold of is polysemous. Type A tends to be the most common translation pattern for this LVC into Spanish although genre differences may show preferences for one construction over another.

Table 3. Support verb constructions with take + noun in the BNC take account of/take into account 1995 take action $\quad 468$

take advantage of * 1289

take a bath 32

take a break $\quad 112$

take a breath $\quad 58$

take care of $\quad 601$

take a decision $\quad 37$

take a dive 20

take a drive 2

take exercise 16

$\begin{array}{lr}\text { take a hike } & 7\end{array}$

take hold 319

take an interest in $\quad 157$

take a look 442

take note/s $\quad 288$

take notice 147

take offence $\quad 70$

take a rest 17

take a root $\quad 70$

take a seat $\quad 95$

take shape 119

take a shower $\quad 32$

take someone's point 62

take time $\quad 600$

take a walk

\section{Get Access}

"Access" is one of many nouns that have been turned into a verb in recent years. Conservatives object to phrases like "you can access your account online" and suggest other alternatives: "use," "reach," or "get access to". Both the full lexical verb and the LVC are frequently found in the news genre. Access as a verb has two basic meanings:

- (v) obtain or retrieve from a storage device; as of information on a computer

- (v) to get to and enter a place (formal) as in the following example from the $\mathrm{BNC}$ :

(5) Not only do other rich countries restrict access to their markets, the EC also dumps surplus food on world markets, depressing the prices on which New Zealand farmers depend (ABE 2030).

Get access has two basic translations into Spanish: An LVC construction and the full lexical verb. See examples 6 and 7 respectively. Notice that other more formal LVC constructions are also possible in Spanish, obtener/tener/conseguir acceso:

(6) These included several on the need to enable developing countries to get access to and training in the use of remotely sensed data from satellites $>$ Varias de esas declaraciones se refieren a la necesidad de permitir que los países en desarrollo tengan acceso a los datos de teledetección vía satélite y se capaciten en su uso (unesdoc.unesco.org).

(7) these figures reflect the level of interest raised and the players' need to get access to joint public funding in order to foster the creation of a provision [...] $>$ Estas cifras reflejan el gran interés suscitado así como la necesidad que tienen los diferentes agentes de acceder a cofinanciaciones públicas a fin de estimular la creación [...] (eur-lex.europa.eu)

\section{Get the Sack}

Students learn the more formal and frequent full lexical verb alternatives (dismiss, fire) but also other frequent uses in current English (make redundant, lay off in American English) and they are taught that the LVC "get the sack" is British informal oral usage meaning "to tell someone that they can no longer work at their job".

Two basic types of translation were identified:

- English construction $\rightarrow$ Spanish full lexical verb (formal register, despedir, in example 8 and informal register, echar a alguien, example 9) 
(8) If Señor Abadía was working for a company, he would get the sack for not doing his job $>$ Si el Señor Abadía trabajara en una empresa, hace tiempo que lo habrían despedido por no cumplir con el trabajo (orihuelacostapsoe.eu).

(9) He got the sack > lo echaron.

English construction $\rightarrow$ Non- Equivalent Spanish LVC:

(10) As a consequence of that, the vast majority of the Jews working for the police, Securitate or the Prosecutors' Office, got the sack $>$ Por tanto, gran parte si no la mayoría de los judíos que trabajan en la Policía, la Seguritate o la Fiscalía, fueron destituidos de sus cargos. (rri.ro)

\section{Get Permission}

Three types of translations are frequent and they are LVCs. There are differences according to register (formal or informal):

English construction $\rightarrow$ Formal written register LVC using a different noun:

(11) Copyright conditions still apply, so the library informs users of the need to get permission from the copyright owner before making copies $>$ Como aún se aplican las condiciones del derecho de autor, la biblioteca informa a los usuarios de la necesidad de solicitar la autorización del titular de los derechos antes de hacer copias. (unesdoc.unesco.org).

English construction $\rightarrow$ Formal written register LVC using same noun

(12) However, the supply is cumbered due to the fact that "Velefarm" must get permission from the relevant Agency within the Ministry to import the medications $>[\ldots]$ entorpecido por el hecho de que Velefarm debe obtener permiso del organismo competente del Ministerio a fin de importar los medicamentos. (daccess-ods.un.org).

English construction $\rightarrow$ Informal register LVC using same noun

(13) Another described gains in negotiation skills: 'Before, the elders would negotiate with my family to get permission for me to come to the group $>[\ldots]$ dirigentes de la comunidad hubieran tenido que negociar con mi familia para que me dieran permiso para formar parte del grupo. (savethechildren.net).
To conclude this section, a fairly common construction is also commented on, get a divorce.

\section{Get a Divorce}

The most common translations are the full lexical verb and the LVC in more formal contexts. Two types of translations were most commonly found:

English construction $\rightarrow$ Same Spanish full lexical verb:

(14) My parents got a divorce and the first couple of years afterward were extremely difficult for my whole family>. Mis padres se divorciaron y los dos años siguientes fueron sumamente difíciles para toda la familia. (copecaredeal.org)

English construction $\rightarrow$ LVC using the same noun

(15) Sometimes a Legal Aid lawyer can even help you get a divorce $>$ Un abogado de Legal Aid hasta le puede ayudar a obtener un divorcio. (tennlegalaid.com)

\section{Get LVCs with Participial Adjectives}

Get married, get lost and get worse are the most frequent LVCs analyzed below. The corresponding full lexical verbs (to marry, to lose and to worsen) have different nuances of meaning compared to the LVCs. Only the first one (to marry vs. get married) is commented below for the sake of brevity.

\section{Get Married}

It is the most frequent construction in this subcategory. Students are reminded there is a difference in meaning with the full lexical verb. This LVC talks about the time two people got married. It makes us think of the wedding whereas the full lexical verb to marry (someone) refers to the time when people come together as husband and wife. Spanish students tend to use a syntactic calque: "I married with someone". English correct usage is shown in example 16:

(16) ARJ 150 Christine's been married to Doc $\mathrm{D}$ for just over a year now.

Two common translations are found into Spanish:

English construction $\rightarrow$ Same Spanish full lexical verb

(17) Such would, for example, be the case if I were to get married and hire my wedding dress in a neighbouring country and then take it back there> Por ejemplo, este sería el caso si yo me fuera a casar y para ello alquilara mi vestido de novia en un país vecino, y luego lo devolviera (europarl.europa.eu) 


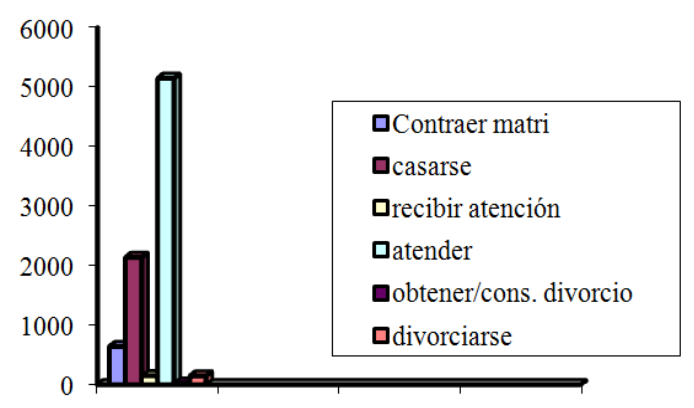

Fig. 4. Quantitative Comparison of Get LVC constructions with full lexical verbs in the Spanish data

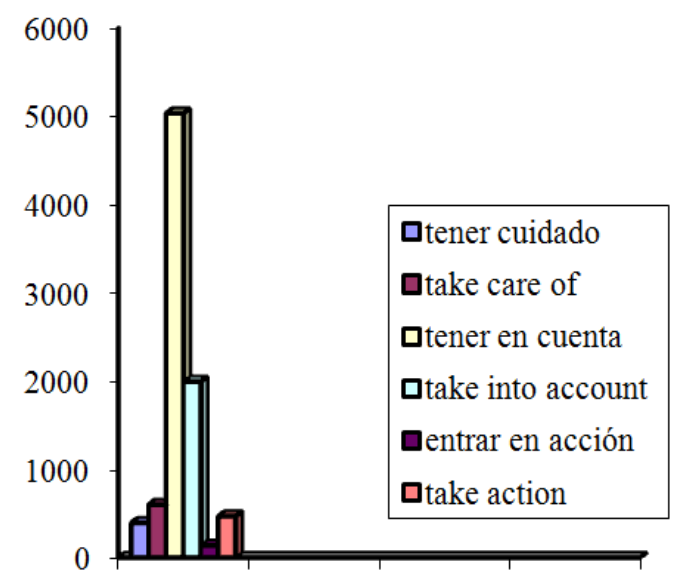

Fig. 5. Quantitative Comparison of Take LVC constructions in the English data and its Spanish equivalents

English construction $\rightarrow$ LVC (formal register)

(18) $[. .$.$] of the Family Code prohibits a person$ under the age of 18 to get married, the next paragraph specifies that paragraph 1 shall not apply $>[\ldots]$ a toda persona de menos de 18 años contraer matrimonio, el párrafo siguiente precisa que el párrafo 1 no se aplicará a una persona (daccess-ods.un.org)

Get Lost

It's the second most frequent LVC. It has two basic meanings illustrated in examples 19 and 20:

- $\quad$ to become lost; to lose one's way.

(19) A2A 540 She had got lost, returning to their home in Ambleside Road, Warndon, Worcester and found herself on the M50.

- Inf. Go away!; Stop being an annoyance! (Always a command)

(20) AT3 2050 Get lost!' he shouted.

Example 19 can only be translated by a full lexical verb into Spanish (perderse, extraviarse) and example
20 by several idiomatic expressions indicating annoyance (see translations in 22 below):

(21) A great idea is to get lost in the tiny streets of this town, (...)> Recomendamos perderse por las callejuelas del pueblo,(...). (balearsculturaltour.es)

(22) vete al Diablo, vete al cuerno, vete a la porra, vete a hacer puñetas.

\section{GET WORSE}

This LVC has two basic meanings in English:

- to deteriorate in health as in:

(23a) CBC 15134 Since we moved here the asthma has got worse.

Not surprisingly, it collocates with pain as in example $23 \mathrm{~b}$ :

(23b) EWX 792 The pain got worse, the GP called and declared "There is no sign of anything wrong with your heart."

- to undergo a transformation or a change of position or action (example 24):

(24) B16 289 Consider, again, the percentage of respondents who believe that the economy got worse over the previous twelve months.

Its antonym LVC is also frequent in English with the meaning "bounce back, get well, get over-improve in health".

To recap get LVCs, the range of nouns found with get in the BNC is the following: the largest category is nouns referring to treatment or a service given to a person or to a thing on behalf of a person, such as abortion, absolution, abuse, acclaim, acquittal, advice, aid, airing, answer, apology, applause, approval, assent, assurance, attention, awakening; a second category refers to an office or power given to a person, such as access, admittance, appointment, authority, award and a last small category refer to a process being begun such as (get an ache), (get into an) argument. The collocational patterning of get + participle has also shown that these LVCs tend to be associated with informative texts. On the whole, the meaning of the stretched verb get is 'to experience something, to contrive to experience something or to begin to experience something'. These findings support those of Allerton (2003: 179). As a final point, examples (16 to 24) from the BNC have shown that when used with a participle, get implies a change 
from a state without the action of the verb to a state with it. For the past participle, that means receiving the action of the verb.

\section{English LVCs with Take}

Most light verb constructions in English with take include a noun; twenty-six common ones have been used for comparison purposes with the former get LVCs. There are a total of 6,920 raw tokens. The infinitive form and the past tense have been included in the counting. Note that the determiner $a$ is usually not part of the LVC because it is variable, e.g., Mary takes a long/the first//the best bath.

Those LVCs marked with an asterisk (*) can take not only a prepositional passive but also can take a passive for which the idiomatically-fixed direct object becomes subject; e.g.:

(25) AN5 641 Relations with the press may cause difficulties and advice should be taken before talking about a pupil.

Spanish tends to use in these cases the reflexive pronoun "se" instead of the standard passive. A search of the Spanish counterpart of take account (of) proves that this collocation is highly abundant in newspapers, with 111 tokens in CREA e.g., esa asociación no se toma en cuenta al empresariado nacional [National employers are not taken account of in that association].

Many LVCs with take are closely similar in meaning to a corresponding full verb, e.g.:

- Mary takes a bath

- Mary bathes

- Mary is taking a look

- Mary is looking

Alternative formulations such as these lead to the insight that LVCs are predicates just like the corresponding full verb alternatives. There can be, however, nuanced differences in meaning across these alternative formulations (Butt 2003). Let's look at the following examples:

a. I took a picture of myself.-The light verb took requires the reflexive pronoun to appear. b. *I took a picture of me.-The light verb took prohibits the simple pronoun from appearing. a. I took a picture of myself to my mother.The full verb took allows the reflexive pronoun to appear.

b. I took a picture of him to my mother.-The full verb took allows the simple pronoun to appear.
In most cases, take as a thin verb is used for action that is beneficial to the speaker, performing a service for them, with some exceptions: take offence is not necessarily of benefit to the recipient. This also seems to be the case with the Spanish counterparts. See Fig. 2 for the five most common uses in the BNC data.

In this corpus-based approach, the collocational patterning of take collocates with words with pleasant connotations such as break, rest, seat. If the starting point is the lexical item, one may find a range of verbs which collocate with the noun. Such is the case with break, which not only collocates with take* but also with have*. Similarly, the word bath, which collocates with *have and *take. Concordancing these two verbs shows that have is associated with informative texts and take has a more positive semantic prosody, as in the following examples:

(26) A7K 1478 the first thing to do is to give them food and shelter, medicine and chance to take a bath, some clothing.

(27) CAM $896 \mathrm{He}$ went off to his room to have a bath and dress.

It is also relevant to point out that take seldom appears interpersonally marked with modal verbs in the BNC such as must or need to, which provide subjective meaning with a deontic value as in 28 and 29:

(28) A7H 1051 'I am one of those people', he has said in the past,' who must take exercise not only to be able to give of my best, but just to survive-I mean, I can't function without it.

(29) FD3 $1180(\ldots)$ one in which the real possibility of the exercise of undue influence in any of its well recognised forms or of misrepresentation is present to the knowledge of the creditor, the creditor must take notice of the position and act reasonably in the circumstances.

Another point of interest is that take appears in imperative forms:

(30) CG2 951 'Take a picture for me please. [...].

(31) BN7 615 Never take exercise without a warm up and cool down.

After examining the highest collocation in our corpus, take advantage of, its collocational patterning was examined. Its 1,289 examples in the BNC show that this support construction is frequently encountered and accessed in English. From the ideational standpoint, this 
collocation is commonly used to provide objective and fact-driven data as in example 32 :

(32) CMU 987 Adult education is part of the further education service and some adult education tutors take advantage of courses offered, such as City and Guilds.

It is fairly obvious, however, that language is multifunctional and the interpersonal function is also prevalent in many instances of this collocation. Lexical markers such as adjectives and adverbs are often stance markers evaluating the content of utterances as hardly in:

(33) FBK 208 However, procurators fiscal hardly ever take advantage of this power.

Take account of is the second highest collocation. It means 'to pay attention to someone or something, take notice of' (example 33), as well as 'to take into consideration'. Many students mix up this LVC with take into account, which only means 'to take into consideration'. Both constructions are so close that many native speakers consider them to be fairly interchangeable:

(34) AM9 689 We will require all government departments to take account of the impact on health of their decisions.

Take care of is the third highest collocation. The key concept is 'care' and falls under the suasion function (Wilkins, 1976: 46), specifically used to persuade, suggest, advise, advocate, etc., that is, affecting the behavior of others. A recommended course of action is put forward to solve an existing problem, as in the following comment from a conversation:

(35) BNL 1781 if your hospital stay is planned then you will have plenty of time to organise some help to take care of your home and other responsibilities.

Last but not least, it is to be noted that there is a dispersion of results in the remaining collocations with take indicating different types of verbal processes. Take shape is found in action processes as many as seventyfive times in the present simple active. Interpersonality is lacking in most of the take shape collocates as in:

(36) HJ4 5155 the new bridges across the Lagan slowly take shape.

However, some of these take collocates may be related to the interpersonal function and tend to have positive semantic prosodies and occupy Rheme position (examples 36 and 37):
(37) AR3 893 I'd like to reach Salisbury in good time to take a look at the city's many charms.

(38) ED1 840 If you're feeling brave you can swim in chilly crystal-clear lakes or take a hike in the mountains.

As a conclusion to the analysis of the BNC data, the findings of the lexico-grammatical patterns of get and take reveal three additional phenomena:

- Texts strongly favour full lexical verbs to verbalize phenomena and processes in the BNC instead of LVCs, as the raw frequency of tokens of marry/get married attest: marry $(2,538)$ vs. get married $(893)$ or walk/ take a walk 10,053 vs. 65 respectively. The Spanish support verb constructions with dar clearly show this preference as well in the CREA: bañar (se)(49) versus darse un baño (2), casarse ( 2,141) vs. contraer matrimonio (243)

- $\quad$ Take as a thin verb in our data suggests action that is beneficial to the speaker

- Lexical variation should be taken into account: there are 145 instances of have a bath in our corpus versus 235 of take a bath. Corpus analysts should therefore analyze not only the verbs but also the nouns as a starting point in order to get the full range of verb collocates.

This study of English LVCs has also revealed that the translation of such expressions is irregular but this is to be expected and such irregularity will be confined to the lexicon. Another interesting finding is that the discussion of get and take LVCs in English and their close translation equivalents in Spanish suggests that both languages exhibit features of semantic prosody. The comparative analysis also shows that close translation equivalents display very similar collocational behavior and semantic prosodies in both languages.

By and large, the work herein presented may be regarded as a step towards a better understanding of collocational links of LVCs for the purpose of learning and Natural Language Processing (NLP). As stated above, phrases with these types of verbs are fairly frequent in English and pose serious problems for learners and translators alike. Point 3.2 discusses the corresponding LVCs in Spanish. Just the most highly used will be commented upon.

\section{Theoretical Underpinnings and Quantitative/Qualitative Analysis of LVCs in the Spanish Data}

The analysis will focus on the three most common collocates for the corresponding get/take constructions, so that the quantitative results of the most common collocates 
in both languages will be discussed. The infinitive and simple past tense have been included in the counting.

The three most common Get LVCs in the Spanish data are: Contraer matrimonio (642), recibir atención (150) and obtener/conseguir el divorcio (27).

These LVCs belong to the formal written register, the examples below from the news genre:

\section{(39) El Rey Alfonso XII contrae matrimonio con su prima María de las Mercedes.}

(40) El acusado, quien fue colocado en el piso, recibió atención médica de emergencia.

(41) A Antonia le ha costado muchos años y muchas púas conseguir el divorcio.

It is also relevant to note that the corresponding full verbs are far more commonly used as shown in Fig. 4. Interestingly, this correlation was also found in the English data.

Students are also reminded that there is not always a one-to-one correspondence between the LVC and the full lexical verb. This is the case with recibir atención ('get attention') versus atender, which has a wider set of meanings: 'to pay attention', 'meet your commitments', 'to be seen' (by a doctor), etc.

The most common three Take LVCs in the CREA are tener en cuenta $(5,035)$ tener cuidado $(395)$ and entrar en acción (139). There is a correlation of these LVCs with the most frequent uses in the BNC corpora as shown in Fig. 5: Tener en cuenta/take into account are the most frequent LVCs in the two corpora, followed by tener cuidado/take care of.

From a wider perspective, Spanish LVCs have been studied by Koike (2001: 69) and he sheds light on the dar+ noun support construction; part of his conclusions are relevant for the present analysis comparing these Spanish LVCs with their English counterparts take + noun. Dar corresponds with take only on certain occasions.

Koike comments that the verb dar ["to give"] is transitive and loses its original semantic meaning when it is used in de-lexicalized verb constructions such as dar un paseo ["to take a walk"]. In very general terms, he also states that dar can be used with either concrete or abstract nouns such dar un paseo["take a walk"] or dar un respiro ["take a break"] respectively.

Furthermore, Koike notices other important facts about dar as a support verb construction:

- Verbs related morphologically to nouns which appear in these support verb collocations do not show a tendency to form collocations themselves. Thus, the verb bañarse does not collocate as the noun baño ["bath"] does with the verb dar in the delexicalized verb constructions dar(se) un baño ["take a bath"]

- Action, motion and sound nouns are compatible with dar such as (i) nouns related to movement: dar(se) un paseo $>$ [ "to take a walk"]

- $d a r+s e$, the impersonal pronoun, has mostly negative semantic prosodies: darse un atracón $>$ to gorge or stuff oneself, darse un batacazo $>$ to fall over and bang your arm, leg, etc., darse una paliza $>$ to work one's butt off (AmE)/to slog one's guts out $(\mathrm{BrE})$ or darse un susto $>$ give him/her a fright. Nevertheless, some are neutral: darse una ducha $>$ to take/have a shower

- Some constructions have a causative value arising from the noun phrase: dar alegria > make sb happy, dar angustia $>$ cause great anguish or distress

- Koike (2001:85) points out that the support verb construction dar + substantive is the most common light verb collocation, followed by tener (to have + noun). The former is a common lexical collocation with different processes

I have studied the equivalent phraseological units with take whenever possible in the Spanish corpus. There are sometimes several possible translations into Spanish as stated above (e.g., take hold $>$ agarrar, coger, extenderse) but I have worked mainly with the direct translation to see the quantitative differences between languages.

Looking at the 63 tokens, the reflexive patterning of $d a r+s e$ normally reflects the literal usage but there are rare occasions when it is used metaphorically as in:

\section{(42) Parece que Aznar está dispuesto a darse} un baño de diplomacia.

Finally, Take LVCs may also be translated into Spanish with other LVCs than "dar" (e.g., take notice> prestar atención/hacer caso; take somebody's advice> hacer caso; take a look> echar un vistazo a alguien and take into account $>$ tomar/tener en cuenta ). Due to space constraints, these support verbs have not been discussed.

\section{Conclusion}

From a strictly phraseological viewpoint, the present paper has tried to offer an overview of the synchronic usage of multiword units in corpus data in English and Spanish. It has focused on LVCs with get and take, comparing them to their Spanish LVCs and showing that they are inherent to language use. The collocational patterns studied are related to what is typically said, rather than what can be said, but they admit lexical, diatopical, register and tense variation. The distinction of LVCs from other complex predicates or arbitrary verb- 
noun combinations is not a simple task. On the syntactic level, the difficulty is that LVCs occur in different forms-e.g., with direct object (contraer matrimonio 'to get married') or prepositional object (tener en cuenta 'take into account'). Semantically, it is challenging to differentiate between LVCs and a fully compositional construction in a corpus-driven fashion.

From a quantitative point of view, there are more support verb constructions with get + noun in English, as it is a frequent de-lexicalized verb according to the Collins Cobuild English Grammar (Sinclair, 1990). Nonetheless, its figures are fairly low with the exception of get hold of. From a qualitative standpoint, this bilingual comparison exercise of LVCs renders interesting insights about certain coincident phenomena in both languages. First of all, these LVCs are related mainly to abstract nouns, although it is also feasible to find some constructions with concrete nouns in Spanish. Secondly, the use of these clusters tends to portray a factual view of reality (take a shower/darse una ducha). Thirdly, nouns play an important role in both English and Spanish collocations because they select the verb and its syntactic demands. This verb selection materializes in collocations like obtener el divorcio ['to get divorced'] since we use the verb obtener (literally, "to get") with the noun divorcio in the LVC obtener el divorcio.

Considering the overall corpus implications of a study like this, it seems to be clear that English as Second Language (ESL) teachers should draw attention to these contrasts if they want their students to use collocations as native speakers do. Obviously, this requires explicit training in the use of collocations, through the use of corpora in class and of LVCs in particular-in accordance with to Common European Framework of Reference for Languages standards-to raise both an awareness of ideational, interpersonal and textual functions and also of authorial and distributional factors at play in each genre. McCarthy (1990: 12) stresses that "the relationship of collocation is fundamental in the study of vocabulary" and thereby is a major area of concern for learners of EFL, which converts bilingual dictionaries of multi-word expressions into an invaluable resource for both learners of EFL and translators. Assuming that "all fluent and appropriate language use requires collocational knowledge" (Nation, 2001: 318), electronic dictionaries become a fundamental instrument for CALL-oriented educational practices.

The pedagogical implications of a study like this are clear. Indeed, the study herein conducted is just an example of the possibilities for foreign language education based on CALL resources. As it is, it is extremely important that students grasp not only the conventional grammar but also these LVCs (obviously with get, take but also with other verbs such as make, give, etc.) in connection with syntax, semantics, pragmatics and each respective culture. Furthermore, awareness of the collocational points of contact and divergence should be raised among teachers and students in order to facilitate acquisition by underscoring the potential lexical, genre and register differences. My teaching experience over the years has proved that students learn English more naturally if encouraged to use and build collocation repertoires in the classroom. As substantiated by the case study herein presented, the use of corpora in class offers great potential for language teaching in general and for collocational knowledge in particular, which seems to be consistent with current trends in corpus linguistics applications of language teaching and learning (Gabrielatos, 2005; Aijmer, 2009).

Although the primary data has been selected from corpora, the Internet is also playing an increasingly crucial role in sorting out the most recurrent and widely used grammatical and lexical collocations as shown in the translation of the English examples.

\section{Acknowledgement}

I gratefully acknowledge the constructive criticism of my reviewers.

\section{Ethics}

The author is willing to address any ethical issue that may arise after the publication of this manuscript.

\section{References}

Aijmer, K., 2009. Corpora and Language Teaching. 1st Edn., John Benjamins, Amsterdam, ISBN-10: 9027289980, pp: 232.

Alba-Salas, J., 2002. Light verb constructions in Romance: a syntactic analysis. Ph.D. Thesis, Cornell University.

Allerton, D.J., 2003. Stretched Verb Constructions in English. 1st Edn., Routledge, ISBN-10: 1134517416, pp: 320.

Bahns, J., 1993. Lexical collocations: A contrastive view. ELT J., 47: 56-63. DOI: 10.1093/elt/47.1.56

Barreiro, J., J. Monti, B. Orliac and F. Batista, 2013. When multiwords go bad in machine translation. Proceedings of the Workshop on Multi-word Units in Machine Translation and Translation Technology, Machine Translation Summit, (WMUM' 13).

Beatty, K., 2003. Computers in the language classroom. In: Practical English Language Teaching. Nunan, D., (Ed.), McGraw Hill, Boston, PP: 247-266.

Beckett, G.H. and P.C. Miller, 2006. Project-Based Second and Foreign Language Education: Past, Present and Future. 1st End., Information Age Publishing, Greenwich, CT., ISBN-10: 1593115067, pp: 286. 
Biber, D., S. Johansson, G. Leech, S. Conrad and E. Finegan, 1999. Longman Grammar of Spoken and Written English. 1st End., Pearson Education, Longman, ISBN-10: 0582237254, pp: 1204.

Blake, R., 2001. What language professionals need to know about technology. ADFL Bull., 32: 93-99.

Butt, M., 2003. The Light Verb Jungle. In Harvard Working Papers in Linguistics, ed. G. Aygen, C. Bowern and C. Quinn. 1-49. Volume 9, Papers from the GSAS/Dudley House workshop on light verbs.

Campoy, M.C., 2004. Computer Mediated Lexicography: An Insight into Online Dictionaries. In: ComputerMediated Lexicography in the Foreign Language Learning Context, Campoy, M.C. and P. Safont (Eds.), Universitat Jaume I, Castelló de la Plana, pp: 47-72.

Cowie, A., 2004. Phraseology-the hornby legacy. Proceedings of the 11th EURALEX International Congress, (IC' 04), Université de Bretagne-Sud, Lorient, pp: 37-52.

Davies, G., 2002. ICT and modern foreign languages: learning opportunities and training needs. Int. J. English Stud., 2: 1-18.

Schryver, G.M., 2003. Lexicographers' dreams in theelectronic-dictionary age*. Int. J. Lexicography, 16: 143-199.

Egbert, J.L., 2005. Conducting research on Call. In: Call Research Perspectives, Egbert, J.L. and G.M. Petrie, (Eds.), Lawrence Erlbaum, Mahwah, NJ., pp: 3-8.

Gabrielatos, C., 2005. Corpora and language teaching: Just a fling, or wedding bells?. TESL-EJ, 8: 1-37.

Godwin-Jones, R., 2005. Messaging, gaming, peer-topeer sharing: Language learning strategies and tools for the millennial generation. Lang. Learn. Technol., 9: 17-22.

Gries, S.T., 2008. Phraseology and Linguistic Theory: a Brief Survey. In: Phraseology. An interdisciplinary perspective, Granger, S. and F. Meunier (Eds.), University of California, USA, pp: 3-26.

Hanson-Smith, E., 2004. Computer-Assisted Language Learning. In: The Cambridge guide to Teaching English to Speakers of other Languages, Carter, R. and D. Nunan (Eds.), Cambridge University Press, Cambridge, pp: 107-113.

Hornero, A.M., M.J. Luzón and S. Murillo, 2006. Corpus Linguistics: Applications for the Study of English. 1st Edn., Peter Lang, Bern, ISBN-10: 303910-675-9, pp: 526

Howarth, P., 1996. Phraseology in English Academic writing: Some Implications for Language Learning and Dictionary Making. 1st Edn., M. Niemeyer, Tübingen, ISBN-10: 348430975X, pp: 230.

Jespersen, O., 1942. A Modern English Grammar on Historical Principles. Allen and Unwin, Copenhagen, London.

Kearns, K., 2002. Light verbs in English.
Koike, K., 2001. Colocaciones Léxicas en el Español Actual: Estudio Formal y Léxico-Semántico. 1st Edn., Universidad de Alcalá, Span, ISBN-10: 8481384763, pp: 275.

Levy, M., 1997. Computer-Assisted Language Learning: Context and Conceptualization. 1st Edn., Clarendon Press, Oxford, ISBN-10: 019823631X, pp: 298.

Lewis, A.L., 2000. Option Valuation under Stochastic Volatility. 1st Edn., Finance Press, Newport Beach, ISBN-10: 0967637201, pp: 350.

López, M. and M.C. Campoy, 2003. User Guides in Computer-Mediated Dictionaries. In: Internet in Linguistics, Translation and Literary Studies, Posteguillo, S., E. Ortells, J.R. Prado, A. Bolaños and A. Alcina (Eds.), Universitat Jaume I Publicaciones, Castelló de la Plana, pp: 439-452.

Luzón, M.J., 1999. Dictionary Websites: Transforming and Adding Value to the Dictionary. In: ComputerMediated Lexicography in the Foreign Language Learning Context, Campoy, M.C. and P. Safont (Eds.), Universitat Jaume I, Castelló de la Plana, pp: 73-94.

McCarthy, M., 1990. Vocabulary. Oxford: Oxford University Press.

Mel'čuk, I., 1993. La Phraseologie et Son Role Dans L'enseignement/Apprentissage D'une Langue Etrangere. Études de linguistique appliqué, 92: 82-113.

Mel'cuk, I., 1996. Lexical Functions: A Tool for the Description of Lexical Relations in a Lexicon. In L. Wanner (Ed.), Lexical Functions in Lexicography and Natural Language Processing, 37-102. Amsterdam/Philadelphia: John Benjamins Publishing Company.

Mills, D., 2000. Enthusiasm, Experience and Collaboration: Technology in the IEI at UIUC. In: Technology-Enhanced Learning Environments, E. Hanson-Smith (Ed.), Alexandria, VA: TESOL.

Molina-Plaza, S. and E.D. Gregorio-Godeo, 2010. Stretched verb collocations with give: Their use and translation into spanish using the BNC and CREA corpora. Recall 22: 191-211.

DOI: $10.1017 / \mathrm{S} 0958344010000078$

Moliner, M., 2000. Diccionario de uso del español. Madrid: Gredos.

Moon, R., 1998. Fixed Expressions and Idioms in English: a Corpus-Based Approach. 1st Edn., Clarendon Press, Oxford, ISBN-10: 019823614X, pp: 338.

Nation, I.S.P., 2001. Learning vocabulary in Another Language. 1st Edn., Cambridge University Press, Cambridge, ISBN-10: 0521800927, pp: 477.

Nattinger, J. and J.D. Carrico, 1992. Lexical Phrases and Language Teaching. 1st End., Shanghai Foreign Language Education Press, Oxford, ISBN-10: 0194371646, pp: 218. 
Oster, U., M.N. Ruiz Madrid and M. Sanz Gil, 2006. Towards the Integration of ICT in Language Learning and Teaching: Reflection and Experience. 1st Edn., Universitat Jaume I, Castelló de la Plana: Universitat Jaume I, ISBN-10: 8480215488, pp: 78.

Ruiz-Madrid, N., 2007. Integration of the ICT in Language Learning. In: Pedagogical Reflections on Learning Languages in Instructed Settings, Usó-Juan, E. and N. Ruiz-Madrid (Eds.), Cambridge Scholars Publishing, Newcastle-upon-Tyne, pp: 62-93.

Sinclair, J., 1990. (Editor-in-Chief) Collins COBUILD English Grammar. London: Collins.

Sinclair, J., 1997. Corpus Evidence in Language Description. In: Teaching and Language Corpora, Wichmann, A., S. Fligelstone, T. McEnery and G. Knowles (Eds.), Longman, New York, pp: 27-39.

Sobkowiak, W., 1999. Pronunciation in EFL MachineReadable Dictionaries. 1st Edn., Motivex, Poznán : Motivex, ISBN-10: 8387314153, pp: 315.

Sokolik, M., 2001. Computers in Language Teaching. In: Teaching English as a Foreign or Second Language Boston, Celce-Murcia, M. (Ed.), Heinle and HeinleThomson Learning, pp: 477-488.

Traugott, E.C., 1999. A Historical Overview of Complex Predicates. In: Brinton, Laurel, J. and Minoji Akimoto (Eds.), John Benjamins, Amsterdam, pp: 239-260.
Warschauer, M., 2001. On-line Communication. In: The Cambridge Guide to Teaching English to Speakers of other Languages. Carter, R. and D. Nunan, (Edn.), Cambridge University Press, Cambridge, pp: 207-212.

Warschauer, M. and R. Kern, 2000. Network-Based Language Teaching: Concepts and Practice. 1st Edn., Cambridge University Press, Cambridge, ISBN-10: 0521667429, pp: 240.

Wierzbicka, A., 1982. Why can you have a drink when you can't *have aneat? Language, 58: 753-799.

Wilkins, D.A., 1976. Notional Syllabuses: a Taxonomy and its Relevance to Foreign Language Curriculum Development. 7th Edn., Oxford University Press, London, ISBN-10: 0194370712, pp: 92.

Wray, A., 2005. Formulaic Language and the Lexicon. 1st Edn., Cambridge University Press, Cambridge, ISBN-10: 0521022126, pp: 348.

Wray, A., 1999. Formulaic language in learners and native speakers. Lang. Teach., 32: 213-231.

DOI: $10.1017 / \mathrm{S} 0261444800014154$ 